\title{
Maize replacement with sorghum and a combination of protease, xylanase, and phytase on performance, nutrient utilization, litter moisture, and digestive organ size in broiler chicken
}

\author{
G.A.M. Pasquali, V.B. Fascina, A.L. Silva, M.M. Aoyagi, E.M. Muro, P.G. Serpa, D.A. Berto, \\ E.S.P.B. Saldanha, and J.R. Sartori
}

\begin{abstract}
We investigated the effects of a combination of protease, xylanase, and phytase in maize- or sorghum-based diets for broilers. Two experiments were conducted with male chicks randomly distributed in a $3 \times 2$ factorial arrangement with three replacement levels of maize with sorghum $(0 \%, 50 \%$, and $100 \%)$ with or without enzymes. In the first trial, 1152 chicks were allotted to 36 floor pens to determine performance, relative organ weight, and litter moisture. A second trial was performed with 150 and 120 chicks allotted in 30 cages with five and four broilers per cage to determine nutrient and energy utilization from 11 to $21 \mathrm{~d}$ and from 25 to $35 \mathrm{~d}$, respectively. Enzyme supplementation improved body-weight gain and feed conversion ratio. Total maize replacement with sorghum compromised body-weight gain from 1 to $14 \mathrm{~d}$ and from 1 to $35 \mathrm{~d}$. Nitrogen retention was reduced by partial and total maize replacement with sorghum at starter phase and by total replacement at grower phase. Enzyme supplementation improved nitrogen retention at starter phase and apparent metabolizable energy at starter and grower phases. Therefore, partial maize replacement with sorghum is viable and on top application of an enzyme blend containing protease, xylanase, and phytase improves performance and nutrient retention of broilers.
\end{abstract}

Key words: maize, sorghum, exogenous enzymes, nutrient retention, broiler chicken.

Résumé : Nous avons examiné les effets d'une combinaison de protéases, xylanases et phytases dans les diètes à base de maïs ou de sorgho chez les poulets à griller. Deux expériences ont été effectuées chez des poussins mâles distribués de façon aléatoire dans un design factoriel $3 \times 2$ avec trois niveaux de remplacement du maïs par le sorgho $(0 \%, 50 \%$ et $100 \%)$ avec ou sans enzymes. Dans la première étude, 1152 poussins ont été alloués à 36 enclos au sol pour déterminer la performance, le poids relatif des organes et l'humidité contenue dans la litière. La deuxième étude a été effectuée avec 150 et 120 poussins attribués à 30 cages avec cinq et quatre poulets par cage pour déterminer l'utilisation des éléments nutritifs et de l'énergie des jours 11 à 21 et des jours 25 à 35 , respectivement. Les suppléments d'enzymes ont amélioré le gain de poids ainsi que l'indice de consommation. Le remplacement total du maïs par le sorgho a compris le gain de poids des jours 1 à 14 et des jours 1 à 35 . La rétention d'azote a été réduit par le remplacement partiel ou total du maïs par le sorgho dans la phase initiale ainsi que par le remplacement total dans la phase de croissance. Les suppléments d'enzymes ont amélioré la rétention d'azote dans la phase initiale et l'énergie métabolisable apparente corrigé pendant les phases initiales et de croissance. Donc, le remplacement partiel du maïs par le sorgho est une solution viable et l'application d'un mélange d'enzymes contenant des protéases, xylanases et phytases améliore la performance et la rétention des éléments nutritifs chez les poulets à griller. [Traduit par la Rédaction]

Mots-clés : maïs, sorgho, enzymes exogènes, rétention des éléments nutritifs, poulet à griller.

Received 1 July 2016. Accepted 19 November 2016.

G.A.M. Pasquali, V.B. Fascina, A.L. Silva, M.M. Aoyagi, E.M. Muro, P.G. Serpa, D.A. Berto, and J.R. Sartori. Department of Breeding and Animal Nutrition, College of Veterinary Medicine and Animal Science, São Paulo State University, Botucatu, São Paulo 18618-970, Brazil.

E.S.P.B. Saldanha. APTA Regional, Regional Research Pole, Brotas, São Paulo 17380-000, Brazil.

Corresponding author: G.A.M. Pasquali (email: ogamp@msn.com).

Copyright remains with the author(s) or their institution(s). This work is licensed under a Creative Commons Attribution 4.0 International License (CC BY 4.0), which permits unrestricted use, distribution, and reproduction in any medium, provided the original author(s) and source are credited. 


\section{Introduction}

For years, sorghum has been used for an alternative feed ingredient to maize in broiler diets due to the lower production cost of sorghum and the similarity in grain compositions. However, most studies with poultry have investigated the effect of maize- or sorghum-based diets and have not taken in account the partial replacement of the dietary cereal grain (Lunedo et al. 2014; Tancharoenrat et al. 2014). Furthermore, inclusion of exogenous enzymes in diets composed by different cereal grains may lead to different responses due to their grain composition and substrate content for the enzymes. Moreover, responses to phytase, protease, and xylanase supplementation may differ in maize- and sorghum-based diets for broilers due to phytate's different concentrations and localizations (Doherty et al. 1982), arabinoxylan content (Choct 2015) and crude protein inherent digestibility and content (Rostagno et al. 2011) in maize and sorghum grains.

Despite higher protein content of sorghum, the digestibility of some essential amino acids, such as lysine, methionine, and threonine, is relatively lower than those of maize (Rostagno et al. 2011). Kafirin is sorghum's main protein, and it has low digestibility (Oria et al. 2000). In addition to kafirin, sorghum is also rich in tannin and phytate, antinutrients that can negatively affect the utilization of energy and nutrients (Selle et al. 2010). Tannin may complex to macromolecular nutrients, such as proteins, making them unavailable (Spencer et al. 1988), whereas phytate mainly binds to minerals from the diet, thus reducing poultry nutrient digestibility (Woyengo and Nyachoti 2013). Moreover, although in maize, phytate is mainly located in the germ, in sorghum grain, phytate is present in the aleurone layers (Doherty et al. 1982). Also, although maize and sorghum are nonviscous grains, maize presents relatively higher insoluble arabinoxylan content than sorghum (Choct 2015).

The use of exogenous enzymes such as phytase, xylanase, and protease in diets for broilers has been widely researched over the last few years to alleviate the negative effects of the phytate-binding ability, cell-wall nutrient encapsulating of nonstarch polysaccharides (NSPs) such as arabinoxylans, and to break down undigested protein fractions.

Therefore, first, this study aimed at assessing the possibility of partial or total maize replacement with sorghum, and second, studying whether the responsiveness of broilers fed diets supplemented with a combination of exogenous enzymes (protease, xylanase, and phytase) could contribute to this nutritional strategy without affecting broilers' growth.

\section{Materials and Methods}

Birds were cared for in accordance with the guidelines established by São Paulo State University Ethical Committee for Animal Use (No. 04/2013 — CEUA).

\section{Experimental design and dietary treatments}

Both experiments were completely randomized in a $3 \times 2$ factorial design ( $0 \%, 50 \%$, and $100 \%$ substitution of maize with sorghum $\times$ inclusion or not of enzyme blend containing protease, xylanase, and phytase). Sorghum was included as a substitute for maize, and enzyme addition was on top, i.e., without considering nutritional value promoted by exogenous enzymes. In diets without the addition of exogenous enzymes, kaolin was used as an inert material to replace enzyme products. Diets were isonitrogenous and isocaloric (Tables 1 and 2), formulated to meet or exceed nutritional requirements recommended by Rostagno et al. (2011) for male broilers with average performance, and divided into four feeding phases. The use of starch and maize gluten meal $(60 \%$ crude protein) in diets containing sorghum aimed to make such diets as nutritive and caloric as maize-based diets. Condensed tannin content of sorghum used in feed was $0.11 \%$, a value determined by near-infrared spectroscopy (NIRS).

Enzyme inclusion levels were used in accordance with the manufacturer's recommendations (DSM Nutritional Products, São Paulo, Brazil): protease and serine endopeptidase (RONOZYME ${ }^{\circledR}$ ProAct), produced by Bacillus licheniformis, 75000 PROT $\mathrm{g}^{-1}$ of product, dosage of $200 \mathrm{mg} \mathrm{kg}^{-1}$ of feed, which corresponds to 15000 PROT $\mathrm{kg}^{-1}$ of feed; xylanase (RONOZYME ${ }^{\circledR} \mathrm{WX}$ ), produced by Thermomyces lanuginosus spp., $1000 \mathrm{FXU} \mathrm{g}^{-1}$ of product, dosage of $150 \mathrm{mg} \mathrm{kg}^{-1}$ of feed, which corresponds to 150 FXU kg ${ }^{-1}$ of feed; and 6-phytase, produced by synthetic genes from Citrobacter braakii expressed in Aspergillus oryzae (RONOZYME ${ }^{\circledR}$ HiPhos GT), 10000 phytase units activity (FYT) $\mathrm{g}^{-1}$, dosage of $100 \mathrm{mg} \mathrm{kg}^{-1}$ of feed, which corresponds to $1000 \mathrm{FYT} \mathrm{kg}^{-1}$ of feed.

A protease unit (PROT) corresponds to the quantity of enzyme that releases $1 \mathrm{mmol}$ of $p$-nitroaniline from $1 \mathrm{mmol} \mathrm{L}^{-1}$ of substrate (Suc-Ala-Ala-Pro-Phe-pNA) $\mathrm{min}^{-1}$ at $\mathrm{pH} 9.0$ at $37^{\circ} \mathrm{C}$. Xylanase activity (FXU) is determined by means of xylanase incubation with remazolxylan substrate, at $\mathrm{pH} 6.0$ at $50{ }^{\circ} \mathrm{C}$ for $30 \mathrm{~min}$ and compared with reference standard activity, xylanase produced by Humicola insolens. One FYT is defined as the quantity of enzyme required to release $1 \mu \mathrm{mol}$ inorganic $\mathrm{P} \mathrm{min}^{-1}$, at $\mathrm{pH} 5.5$, from an excess of $15 \mu \mathrm{mol} \mathrm{L}^{-1}$ sodium phytate at $37^{\circ} \mathrm{C}$.

\section{Trial I: performance, relative organ weight, and litter moisture}

A total of $1152 \mathrm{~d}$ old male broiler chicks (Cobb) were obtained from a commercial hatchery and placed in 36 floor pens, distributed into six dietary treatments with six replicate pens with 32 broilers each. Birds were housed in $2 \mathrm{~m}^{2}$ floor pens, with $15 \mathrm{~cm}$ thick wood shavings litter, equipped with tubular feeder and nipple drinker.

Average body-weight gain, feed intake, and feed conversion ratio adjusted for mortality were obtained by 
Table 1. Dietary composition and calculated nutrient content for prestarter and starter phases.

\begin{tabular}{|c|c|c|c|c|c|c|}
\hline & \multicolumn{3}{|c|}{ Pre-starter (1-7 d) } & \multicolumn{3}{|c|}{ Starter (8-21 d) } \\
\hline & $0 \%$ & $50 \%$ & $100 \%$ & $0 \%$ & $50 \%$ & $100 \%$ \\
\hline \multicolumn{7}{|l|}{ Item $\left(\mathrm{g} \mathrm{kg}^{-1}\right)$} \\
\hline Maize & 548.9 & 282.9 & - & 590.8 & 303.8 & - \\
\hline Sorghum $^{a}$ & - & 282.9 & 558.9 & - & 303.8 & 598.8 \\
\hline Soybean meal $45 \%$ & 383.6 & 344.3 & 323.7 & 348.3 & 308.5 & 281.9 \\
\hline Soybean oil & 22.6 & 23.4 & 28.0 & 22.1 & 23.5 & 27.2 \\
\hline Maize gluten $60 \%$ & - & 20.0 & 30.0 & - & 20.0 & 34.0 \\
\hline Maize starch & - & - & 11.9 & - & - & 16.3 \\
\hline Dicalcium phosphate & 19.1 & 19.1 & 19.0 & 15.1 & 15.1 & 15.1 \\
\hline Limestone & 9.1 & 9.3 & 9.6 & 9.2 & 9.5 & 9.6 \\
\hline Sodium chloride & 3.5 & 3.5 & 3.5 & 3.5 & 3.5 & 3.5 \\
\hline DL-Methionine (Met) & 3.6 & 3.6 & 3.7 & 2.8 & 2.9 & 3.0 \\
\hline Lysine HCl (Lys) & 2.8 & 3.9 & 4.5 & 2.1 & 3.2 & 4.0 \\
\hline L-Threonine (Thr) & 1.0 & 1.3 & 1.5 & 0.6 & 0.8 & 1.1 \\
\hline Sodium bicarbonate & 2.3 & 2.3 & 2.3 & 1.9 & 1.9 & 1.9 \\
\hline Vitamin + mineral premix ${ }^{b}$ & 2.0 & 2.0 & 2.0 & 2.0 & 2.0 & 2.0 \\
\hline Choline chloride & 0.6 & 0.6 & 0.6 & 0.6 & 0.6 & 0.6 \\
\hline Enzymes or inert $^{c}$ & 0.45 & 0.45 & 0.45 & 0.45 & 0.45 & 0.45 \\
\hline \multicolumn{7}{|l|}{ Calculated specifications } \\
\hline Metabolizable energy (ME; kcal kg-1) & 2,950 & 2,950 & 2,950 & 3,000 & 3,000 & 3,000 \\
\hline $\mathrm{ME}\left(\mathrm{MJ} \mathrm{kg}^{-1}\right)$ & 12.35 & 12.35 & 12.35 & 12.56 & 12.56 & 12.56 \\
\hline Crude protein & 222.0 & 222.0 & 222.0 & 208.0 & 208.0 & 208.0 \\
\hline Calcium & 9.2 & 9.2 & 9.2 & 8.2 & 8.2 & 8.2 \\
\hline Available phosphorus (P) & 4.7 & 4.7 & 4.7 & 3.9 & 3.9 & 3.9 \\
\hline Digestible Met & 6.5 & 6.5 & 6.6 & 5.6 & 5.7 & 5.7 \\
\hline Digestible sulphur amino acid & 9.4 & 9.4 & 9.4 & 8.5 & 8.5 & 8.5 \\
\hline Digestible Lys & 13.1 & 13.1 & 13.1 & 12.0 & 12.0 & 12.0 \\
\hline Digestible Thr & 8.5 & 8.5 & 8.5 & 7.6 & 7.6 & 7.6 \\
\hline Sodium & 2.2 & 2.2 & 2.2 & 2.1 & 2.1 & 2.1 \\
\hline Chloride & 2.6 & 2.6 & 2.6 & 2.6 & 2.6 & 2.6 \\
\hline Potassium & 8.6 & 8.1 & 7.9 & 8.1 & 7.6 & 7.2 \\
\hline
\end{tabular}

${ }^{a}$ Condensed tannin concentration was $0.11 \%$ determined by NIRS.

${ }^{b}$ Vitamin + mineral premix provided $\mathrm{kg}^{-1}$ of feed: vitamin A, 11092 IU; vitamin $\mathrm{D}_{3}, 2678 \mathrm{IU}$; vitamin E, $24.86 \mathrm{IU}$; folic acid, $0.99 \mathrm{mg}$; D-panthotenic acid, $11.78 \mathrm{mg}$; vitamin $\mathrm{B}_{6}, 2.49 \mathrm{mg}$; biotin, $0.1 \mathrm{mg}$; niacin, $30.0 \mathrm{mg}$; vitamin $\mathrm{B}_{2}, 4.5 \mathrm{mg}$; vitamin $\mathrm{B}_{1}, 2.01 \mathrm{mg}$; vitamin $\mathrm{B}_{12}, 12.00 \mu \mathrm{g}$; vitamin $\mathrm{K}_{3}$, 1.89 mg; Fe, 49.60 mg; Cu, 8.56 mg; Mn, 66.6 mg; Zn, 51.36 mg; I, 1.0 mg; Se, 0.3 mg; salinomicin, $60 \mathrm{mg}$; virginiamycin, $16.5 \mathrm{mg}$.

${ }^{c}$ Enzyme blend: protease $\left(200 \mathrm{mg} \mathrm{kg}^{-1}\right)$, xylanase $\left(150 \mathrm{mg} \mathrm{kg}^{-1}\right)$, and phytase $\left(100 \mathrm{mg} \mathrm{kg}^{-1}\right)$; inert: kaolin.

weighing broilers and feed weekly. Mortality rate was registered daily for each experimental unit.

At 21 and $42 \mathrm{~d}$ of age, one and two birds per experimental unit, respectively, were taken from the floor pen, according to their average body weight, weighed, and sacrificed by cervical dislocation after fasting for $2 \mathrm{~h}$. Subsequently, proventriculus, gizzard, small intestine, large intestine, liver, and pancreas were removed and weighed. Afterward, relative weights were calculated in relation to broiler body weight. The intestines were emptied, and proventriculus and gizzard fat were removed before being weighed.

Litter moisture was determined weekly, through litter samples from five different places in each floor pen, from the surface to the bottom, far from the nipple drinker and feeder area. The litter samples were stored in plastic bags and homogenized, and immediately, $70 \mathrm{~g}$ portions were taken and weighed in aluminum trays. The samples were dried in a forced ventilation oven at $65{ }^{\circ} \mathrm{C}$ for $24 \mathrm{~h}$, according to the methods described by Association of Official Analytical Chemists (AOAC 2000).

Trial II: energy and nutrient retention and total tract transit time

Two metabolism tests were carried out, with a total of 150 male broiler chicks from day 11 to day 21 (starter phase) and a total of 120 male broiler chicks from day 25 to day 35 (grower phase). Broilers used in trials were obtained from a commercial hatchery and fed a maize- and soybean meal-based diet from placement until the beginning of each experimental period. From 
Table 2. Dietary composition and calculated nutrient content for grower and finisher phases.

\begin{tabular}{|c|c|c|c|c|c|c|}
\hline & \multicolumn{3}{|c|}{ Grower (22-35 d) } & \multicolumn{3}{|c|}{ Finisher (36-42 d) } \\
\hline & $0 \%$ & $50 \%$ & $100 \%$ & $0 \%$ & $50 \%$ & $100 \%$ \\
\hline \multicolumn{7}{|l|}{ Item (g kg-1) } \\
\hline Maize & 617.4 & 317.1 & - & 6649 & 340.0 & - \\
\hline Sorghum $^{a}$ & - & 317.1 & 646.1 & - & 340.0 & 697.8 \\
\hline Soybean meal $45 \%$ & 316.1 & 275.9 & 243.5 & 2740 & 235.7 & 192.3 \\
\hline Soybean oil & 31.8 & 33.6 & 37.7 & 299 & 33.0 & 35.5 \\
\hline Maize gluten $60 \%$ & - & 20.0 & 34.8 & - & 18.4 & 39.7 \\
\hline Dicalcium phosphate & 12.7 & 12.7 & 12.7 & 10.7 & 10.7 & 10.7 \\
\hline Limestone & 8.6 & 8.9 & 9.1 & 7.7 & 7.9 & 8.2 \\
\hline Sodium chloride & 3.5 & 3.5 & 3.5 & 3.5 & 3.5 & 3.5 \\
\hline DL-Methionine (Met) & 2.5 & 2.6 & 2.7 & 2.4 & 2.4 & 2.5 \\
\hline Lysine $\mathrm{HCl}$ (Lys) & 1.9 & 3.0 & 3.9 & 2.3 & 3.4 & 4.6 \\
\hline L-Threonine (Thr) & 0.4 & 0.7 & 0.9 & 0.5 & 0.8 & 1.1 \\
\hline Sodium bicarbonate & 1.6 & 1.6 & 1.6 & 1.4 & 1.4 & 1.4 \\
\hline Vitamin + mineral premix ${ }^{b}$ & 2.0 & 2.0 & 2.0 & 2.0 & 2.0 & 2.0 \\
\hline Choline chloride & 0.5 & 0.5 & 0.5 & 0.4 & 0.4 & 0.4 \\
\hline Enzymes or inert $^{c}$ & 0.45 & 0.45 & 0.45 & 0.45 & 0.45 & 0.45 \\
\hline \multicolumn{7}{|l|}{ Calculated specifications } \\
\hline Metabolizable energy (ME; $\mathrm{kcal} \mathrm{kg}^{-1}$ ) & 3,100 & 3,100 & 3,100 & 3,150 & 3,150 & 3,150 \\
\hline $\mathrm{ME}\left(\mathrm{MJ} \mathrm{kg}{ }^{-1}\right)$ & 12.98 & 12.98 & 12.98 & 13.19 & 13.19 & 13.19 \\
\hline Crude protein & 195.0 & 195.0 & 195.0 & 180.0 & 180.0 & 180.0 \\
\hline Calcium & 7.3 & 7.3 & 7.3 & 6.4 & 6.4 & 6.4 \\
\hline Available phosphorus (P) & 3.4 & 3.4 & 3.4 & 3.0 & 3.0 & 3.0 \\
\hline Digestible Met & 5.2 & 5.2 & 5.3 & 4.9 & 4.9 & 5.0 \\
\hline Digestible sulphur amino acid & 7.9 & 7.9 & 7.9 & 7.4 & 7.4 & 7.4 \\
\hline Digestible Lys & 10.8 & 10.8 & 10.8 & 10.1 & 10.1 & 10.1 \\
\hline Digestible Thr & 7.0 & 7.0 & 7.0 & 6.6 & 6.6 & 6.6 \\
\hline Sodium & 2.0 & 2.0 & 2.0 & 2.0 & 2.0 & 2.0 \\
\hline Chloride & 2.6 & 2.6 & 2.6 & 2.6 & 2.6 & 2.6 \\
\hline Potassium & 7.6 & 7.1 & 6.7 & 6.9 & 6.5 & 5.9 \\
\hline
\end{tabular}

${ }^{a}$ Condensed tannin concentration was $0.11 \%$ determined by NIRS.

${ }^{b}$ Vitamin + mineral premix provided $\mathrm{kg}^{-1}$ of feed: vitamin A, $11092 \mathrm{IU}$; vitamin $\mathrm{D}_{3}, 2678 \mathrm{IU}$; vitamin $\mathrm{E}$, $24.86 \mathrm{IU}$; folic acid, $0.99 \mathrm{mg}$; D-panthotenic acid, $11.78 \mathrm{mg}$; vitamin $\mathrm{B}_{6}, 2.49 \mathrm{mg}$; biotin, $0.1 \mathrm{mg}$; niacin, $30.0 \mathrm{mg}$; vitamin $\mathrm{B}_{2}, 4.5 \mathrm{mg}$; vitamin $\mathrm{B}_{1}, 2.01 \mathrm{mg}$; vitamin $\mathrm{B}_{12}, 12.00 \mu \mathrm{g}$; vitamin $\mathrm{K}_{3}, 1.89 \mathrm{mg}$; Fe, 49.60 mg; Cu, 8.56 mg; Mn, 66.6 mg; Zn, 51.36 mg; I, 1.0 mg; Se, 0.3 mg; salinomicin, 60 mg; virginiamicin, $16.5 \mathrm{mg}$.

${ }^{c}$ Enzyme blend: protease $\left(200 \mathrm{mg} \mathrm{kg}^{-1}\right)$, xylanase $\left(150 \mathrm{mg} \mathrm{kg}^{-1}\right)$, and phytase (100 $\left.\mathrm{mg} \mathrm{kg}^{-1}\right)$; inert: kaolin.

those periods on, experimental diets were offered to birds until the end of the metabolism testing. During the tests, broilers were housed in a total of 30 galvanized wire battery cages $(60 \mathrm{~cm} \times 50 \mathrm{~cm} \times 40 \mathrm{~cm})$ equipped with trough feeders and nipple drinkers, with five cages per treatment in both trials, and five birds per cage in the starter phase, and four birds per cage in the grower phase.

The metabolism tests were carried out for $10 \mathrm{~d}$ (i.e., $5 \mathrm{~d}$ to adapt to the experimental diet and $5 \mathrm{~d}$ to excreta collection), conducted twice daily (at 0800 and 1700), using a total excreta collection method. The excreta collected from each experimental unit were stored and frozen at $-20{ }^{\circ} \mathrm{C}$, and after that, homogenized for analysis. Feeds were weighed at the beginning and end of the collecting period to determine the feed intake.
After excreta homogenization, portions were taken and dried in a forced ventilation oven at $65 \pm 5{ }^{\circ} \mathrm{C}$ for $72 \mathrm{~h}$. Total dry matter (DM) content of the samples was determined by oven drying at $105{ }^{\circ} \mathrm{C}$. Total nitrogen content of the experimental feeds and excreta was determined using micro-Kjeldahl method and gross energy (GE) using a bomb calorimeter (C-2000 Basic, IKA ${ }^{\circledR}$, Werke). Values of $\mathrm{N}$ and $\mathrm{DM}$ retention were obtained by the following equation:

$$
\begin{aligned}
\mathrm{N}(\%)= & {\left[\left(\text { feed intake } \times \mathrm{N}_{\text {diet }}\right)-\left(\text { excreta output } \times \mathrm{N}_{\text {excreta }}\right)\right.} \\
& \left./\left(\text { feed intake } \times \mathrm{N}_{\text {diet }}\right)\right] \times 100 \\
\mathrm{DM}(\%)= & {\left[\left(\text { feed intake } \times \mathrm{DM}_{\text {diet }}\right)-\left(\text { excreta output } \times \mathrm{DM}_{\text {excreta }}\right)\right.} \\
& \left./\left(\text { feed intake } \times \mathrm{DM}_{\text {diet }}\right)\right] \times 100
\end{aligned}
$$




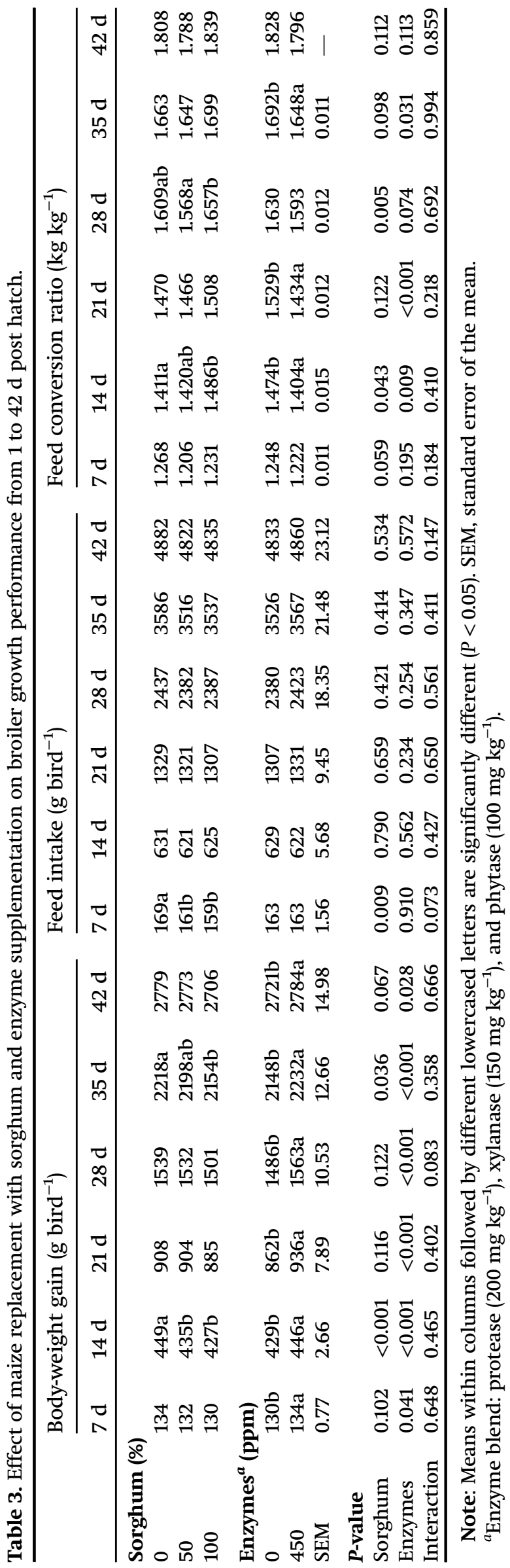

Values of nitrogen-corrected apparent metabolizable energy (AMEn) were obtained by equations proposed by Matterson et al. (1965) and expressed in $\mathrm{MJ} \mathrm{kg}^{-1}$.

$$
\begin{aligned}
& \mathrm{AMEn}_{\text {diet }}=\left[\left(\text { feed intake } \times \mathrm{GE}_{\text {diet }}\right)\right. \\
& \left.-\left(\text { excreta output } \times \mathrm{GE}_{\text {excreta }} \pm 8.22 \times \mathrm{N} \text { retention }\right)\right] \\
& \quad / \text { feed intake }
\end{aligned}
$$

Total tract transit time was determined according to the elapsed time from the beginning of feed consumption until the appearance of excreta with the indigestible marker's characteristic colour (ferric oxide $2 \%$ ) in each experimental unit.

\section{Statistical analysis}

Data were subjected to analysis of variance $(P<0.05)$ with two factors using the general linear model procedure of SAS version 9.0 (SAS Institute, Inc. 2002). Mean separation was adjusted by Tukey's test with $P<0.05$ as the significance level; $P$-values $>0.05$ and $<0.10$ were presented if data suggested a trend. Data normality was tested using univariate procedure of SAS and the Shapiro-Wilk test.

\section{Results}

There was no interaction for any of the parameters measured except for DM retention from 11 to $21 \mathrm{~d}$ post hatch.

\section{Growth performance}

The performance results are shown in Table 3. Mortality rate was $5.5 \%$ from day 1 to day 42 and was not affected by experimental diets.

Partial or total replacement of maize with sorghum reduced feed intake from 1 to $7 \mathrm{~d}$ post hatch $(P<0.05)$. Body-weight gain was reduced with partial or total replacement of maize with sorghum from 1 to $14 \mathrm{~d}$ post hatch $(P<0.01)$ and with total replacement from 1 to $35 \mathrm{~d}$ compared with broilers fed maize-based diets $(P<0.05)$. Despite being not significant, total maize replacement with sorghum tended to decrease bodyweight gain from 1 to $42 \mathrm{~d}$ post hatch $(P=0.067)$ and to impair the feed conversion ratio from 1 to $35 \mathrm{~d}$ post hatch $(P=0.098)$.

Enzyme supplementation improved body-weight gain from 1 to $7(P<0.05), 1$ to $14(P<0.01), 1$ to $21(P<0.01)$, 1 to $28(P<0.01), 1$ to $35(P<0.01)$, and 1 to $42 \mathrm{~d}$ post hatch $(P<0.05)$. Feed conversion ratio was improved from 1 to $14(P<0.05), 1$ to $21(P<0.05)$, and 1 to $35 d$ post hatch $(P<0.05)$ when enzymes were added to diets regardless of the cereal grain $(P<0.05)$.

\section{Nutrient retention and total tract transit time}

Data related to nutrient retention and total tract transit time from day 11 to day 21 and day 25 to day 35 are shown in Table 4. There was interaction between the level of maize replacement with sorghum and enzyme supplementation on DM retention from day 11 to day 21 . Total 
Table 4. Effect of maize replacement with sorghum and enzyme supplementation on nutrient utilization and total tract transit time from 11 to 21 and 25 to $35 \mathrm{~d}$ post hatch.

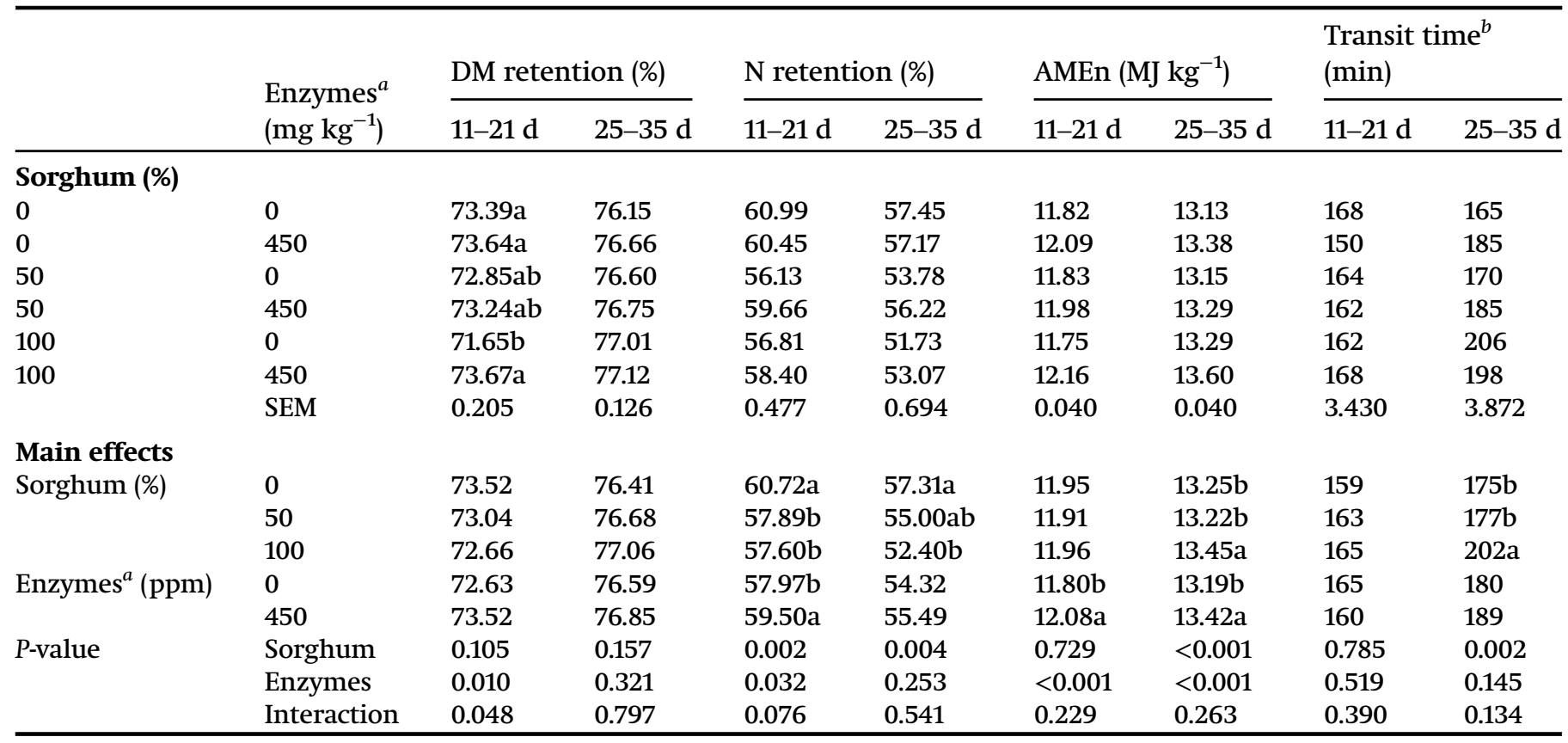

Note: Means within columns followed by different lowercased letters are significantly different $(P<0.05)$. SEM, standard error of the mean.

${ }^{a}$ Enzyme blend: protease $\left(200 \mathrm{mg} \mathrm{kg}^{-1}\right)$, xylanase $\left(150 \mathrm{mg} \mathrm{kg}^{-1}\right)$, and phytase $\left(100 \mathrm{mg} \mathrm{kg}^{-1}\right)$.

${ }^{b}$ Time elapsed from the beginning of feed consumption until the appearance of excreta with indigestible marker's characteristic colour.

replacement of maize with sorghum reduced DM retention $(P<0.05)$, and enzyme supplementation improved DM retention in broilers fed a sorghum-based diet. Enzyme supplementation increased nitrogen $(\mathrm{N})$ retention from 11 to $21 \mathrm{~d}$ post hatch $(P<0.05)$ and AMEn in both periods assessed $(P<0.01)$. Despite being not significant, responsiveness of $\mathrm{N}$ retention to enzyme supplementation of birds fed diets containing sorghum tended to be higher $(P=0.076)$ than those fed corn-based diets.

Nitrogen retention was reduced with partial and total maize replacement with sorghum from 11 to $21 \mathrm{~d}$ post hatch $(P<0.01)$. From 25 to $35 \mathrm{~d}$ post hatch only, total replacement of maize with sorghum reduced $\mathrm{N}$ retention $(P<0.01)$. Sorghum-based diets increased total tract transit time $(P<0.01)$ and AMEn $(P<0.01)$ from 25 to $35 \mathrm{~d}$ post hatch.

\section{Relative organ weight}

Results from the analysis of relative organs weight of the digestive tract are shown in Table 5.

Broilers fed diets containing exogenous enzymes presented a reduction in relative gizzard weight $(P<0.05)$ and small intestine weight $(P<0.01)$ at $21 \mathrm{~d}$ post hatch. Maize replacement with sorghum did not affect the relative organs weight at 21 and $42 \mathrm{~d}$ post hatch, and neither did the supplementation of exogenous enzymes on day 42 .

\section{Litter moisture}

Litter moisture is presented in Table 6. Enzyme supplementation increased litter moisture at $7 \mathrm{~d}(P<0.01)$ and $42 \mathrm{~d}(P<0.05)$. Total replacement of maize with sorghum reduced litter moisture compared with a maize-based diet on day $14(P<0.01)$. Partial and total replacement of maize with sorghum reduced litter moisture at $35 \mathrm{~d}$ post hatch $(P<0.05)$ and $42 \mathrm{~d}$ post hatch $(P<0.01)$ compared with the maize-based diet.

\section{Discussion}

This study observed that the inclusion of protease, xylanase, and phytase progressively improved broiler body-weight gain up to day 21 and, from this period on, the positive effects were gradually reduced until the end of the grower phase. Broilers fed diets containing exogenous enzymes presented greater body-weight gain $+3.1 \%$ (7 d), $+3.9 \%$ (14 d), $+8.6 \%$ (21 d), $+5.2 \%$ ( $28 \mathrm{~d}$ ), $+3.9 \%$ $(35 \mathrm{~d})$, and $+2.3 \%$ ( $42 \mathrm{~d}$ ) compared with birds that were not fed enzyme-supplemented diets, showing that the positive response to the inclusion of exogenous enzymes in diets was more significant in young broilers at starter phases.

In this study, the improvement in the starter performance promoted by exogenous enzymes can be attributed to a better use of dietary nutrients, evidenced by the increase in $\mathrm{N}$ retention (+2.6\%) and AMEn (+2.4\%). According to Sakomura et al. (2004), activities of 


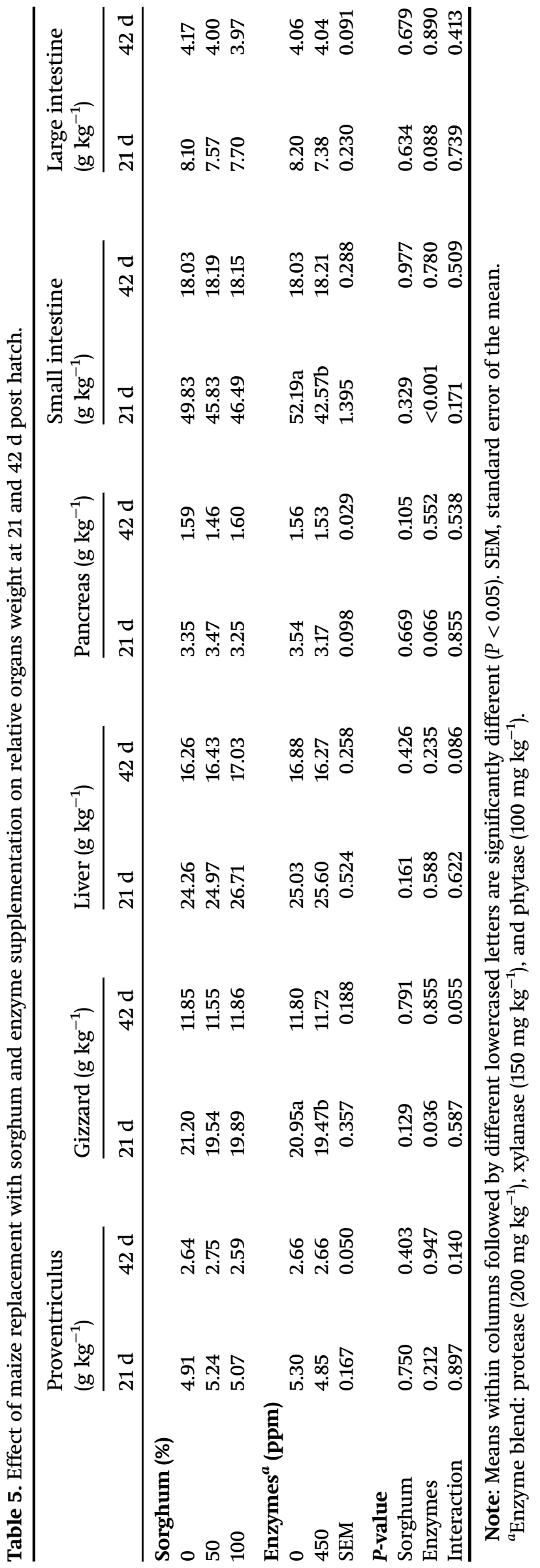

pancreatic enzymes involved in digestion such as amylase, trypsin, and lipase increase as the birds age, especially in the second week of life, when the pancreas is almost fully developed. Therefore, it can be inferred that the inclusion of exogenous protease in diets complemented the activity of endogenous proteolytic enzymes in the poultry digestive tract, improving nutrient metabolizability parameters during the first weeks of age, and consequently, improving performance due to a better feed conversion ratio.

The benefits of including protease, xylanase, and phytase regarding DM retention $(+2.8 \%)$ in $100 \%$ maize replacement with sorghum diets from day 11 to day 21 show that nutrient retention in a sorghum-based diet was inferior compared with maize; however, this effect can be mitigated by enzyme supplementation. The lower DM digestibility may be explained by the lower retention rate of nitrogen in sorghum-based diets, probably due to kafirin's low digestibility rate, which is sorghum's main protein, and the existence of tannin.

Reduced feed intake of broilers fed diets containing sorghum in the first week may be related to the astringent taste of tannins found in sorghum when in contact with salivary proteins. In this study, this can impair feed palatability (Butler et al. 1984), even when a low-tannin sorghum $(0.11 \%$ tannin concentration) is used and may reduce body-weight gain up to $11.5 \%$ in the first week of age (Thomas and Ravindran 2008). In this study, body-weight gain was reduced with partial $(-3.12 \%)$ and total $(-4.90 \%)$ replacement of maize with sorghum from 1 to $14 \mathrm{~d}$ post hatch. Such reduction may be attributed to worse $\mathrm{N}$ retention and lower feed intake with inclusion of sorghum.

Partial and total replacements of maize with sorghum reduced $\mathrm{N}$ retention in the starter phase, $4.66 \%$ and $5.14 \%$, respectively, in comparison with a maize-based diet. Reduced digestibility of sorghum protein may be related to karifin's low digestibility (Wong et al. 2010) and the existence of condensed tannin, which is capable of binding to dietary proteins (Hagerman et al. 1998). Nevertheless, in the grower phase, only the total replacement of maize with sorghum impaired $\mathrm{N}$ retention. Reduced body-weight gain from 1 to $35 \mathrm{~d}$ only with total replacement of maize with sorghum may be attributed to worse $\mathrm{N}$ retention.

Surprisingly, in this study, AMEn in sorghum-based diets was higher than in maize-based diets or diets with partial replacement of maize with sorghum in the grower phase. This effect can be attributed to longer feed retention time, evidenced by a longer transit time when using sorghum-based diets. The increase in transit time may be related to the higher inclusion of oil $(3.77 \%)$ in sorghum-based diets in the grower phase. Besides providing energy, vegetable oil has extra caloric effects, such as increased feed retention time in the digestive tract (Mateos et al. 1982), thus improving energy and nutrient digestion and absorption. Also, sorghum may 
Table 6. Effect of maize replacement with sorghum and enzyme supplementation on litter moisture.

\begin{tabular}{lllllll}
\hline \multicolumn{7}{l}{ Litter moisture (\%) } \\
\cline { 2 - 7 } & $7 \mathrm{~d}$ & $14 \mathrm{~d}$ & $21 \mathrm{~d}$ & $28 \mathrm{~d}$ & $35 \mathrm{~d}$ & $42 \mathrm{~d}$ \\
\hline Sorghum (\%) & & & & & & \\
0 & 9.83 & $17.70 \mathrm{a}$ & 21.22 & 25.65 & $28.92 \mathrm{a}$ & $30.39 \mathrm{a}$ \\
50 & 10.94 & $16.38 \mathrm{ab}$ & 20.90 & 24.50 & $26.37 \mathrm{~b}$ & $25.93 \mathrm{~b}$ \\
100 & 9.59 & $14.71 \mathrm{~b}$ & 20.69 & 25.12 & $26.27 \mathrm{~b}$ & $27.38 \mathrm{~b}$ \\
Enzymes $^{a}$ (ppm) & & & & & & \\
0 & $9.40 \mathrm{~b}$ & 16.29 & 20.77 & 24.86 & 27.15 & $26.99 \mathrm{~b}$ \\
450 & $10.84 \mathrm{a}$ & 16.23 & 21.09 & 25.31 & 27.22 & $28.81 \mathrm{a}$ \\
SEM & 0.31 & 0.37 & 0.42 & 0.52 & 0.42 & 0.49 \\
P-value & & & & & & \\
Sorghum & 0.092 & 0.002 & 0.891 & 0.657 & 0.012 & $<0.001$ \\
Enzymes & 0.010 & 0.923 & 0.730 & 0.661 & 0.925 & 0.016 \\
Interaction & 0.055 & 0.149 & 0.732 & 0.103 & 0.723 & 0.051 \\
\hline
\end{tabular}

Note: Means within columns followed by different lowercased letters are significantly different $(P<0.05)$. SEM, standard error of the mean.

${ }^{a}$ Enzyme blend: protease $\left(200 \mathrm{mg} \mathrm{kg}^{-1}\right)$, xylanase $\left(150 \mathrm{mg} \mathrm{kg}^{-1}\right)$, and phytase $\left(100 \mathrm{mg} \mathrm{kg}^{-1}\right)$.

presents relatively reduced starch digestion coefficients in comparison with maize, and feedstuffs with low starch digestion usually stay longer in the small intestine of birds (Weurding et al. 2001). Moreover, a higher inclusion of maize gluten in $100 \%$ sorghum diets may be related to higher energy retention due to high metabolizable energy content of this feed ingredient (Brumano et al. 2006). In spite of that, growth performance was not improved by higher AMEn in sorghumbased diets, as birds showed poorer performance when fed those diets.

Maize replacement with sorghum did not affect relative organs weight at 21 and $42 \mathrm{~d}$ post hatch. Similar results were found by Thomas and Ravindran (2008), when sorghum-based diets did not affect the weight of digestive tract organs compared with maize-based diets. In this study, enzymes reduced the relative weight of the gizzard and small intestine at day 21. It is known that the presence of NSPs in diets can impair access of digestive enzymes to their substrates, thus, modifying the structure and functions of digestive organs. To minimize such a negative effect, digestive organs can be enlarged due to a greater need for enzyme secretion (Ikegami et al. 1990). On that account, the enzyme addition is likely to have minimized such a response in organs of the digestive tract due to less need for enzyme secretion, thus, reducing the size of the gizzard and small intestine (Wang et al. 2005). Similar results were found by $\mathrm{Wu}$ et al. (2004) and Zhu et al. (2014) in diets supplemented with exogenous enzymes. Furthermore, a decrease in the relative small intestine weight is indicative of less cell proliferation and, consequently, less of a maintenance requirement for this organ (Adeola and Cowieson 2011). In this study, exogenous enzymes improved energy and nutrient utilization in the starter phase, thus, reducing the quantity of substrates that pass through the digestive tract, which could be used by pathogenic microorganisms, thus reducing cell proliferation in the intestinal epithelium (Brenes et al. 2002).

Supplementation of exogenous enzymes increased litter moisture by $15.3 \%$ and $6.7 \%$ at 7 and $42 \mathrm{~d}$, respectively. It is known that the use of phytase may reduce endogenous losses of sodium due to phytate breakdown in avian gut (Liu et al. 2008). Therefore, it is possible that the use of phytase without properly adjusting the level of sodium in the diet may have increased the content of such a mineral in the digestive tract, increasing excreta moisture, and consequently, litter moisture. Farahat et al. (2013) and Pos et al. (2003) observed an increase in litter moisture with phytase supplementation in diets for turkeys and broilers, respectively. This effect could also be due to an increase in digesta osmolarity of broilers fed diets with phytase, attributed to the release of more cations than anions in the early stages of degradation of phytate, because 6-phytase acts cyclically, releasing gradually cations and anions in unequal proportions (Letourneau-Montminy et al. 2011). Therefore, there is a disproportionate release of cations and anions, increasing water excretion in the intestine and urine production, thus, increasing litter moisture. Furthermore, enzyme supplementation improved AMEn only in the grower phase, not showing any effect on nitrogen retention, which may have caused a lack of proportion in the relationship between energy and protein, increasing water intake (Huang et al. 2011), and, consequently, excreta and litter moisture.

The total replacement of maize with sorghum reduced litter moisture on day 14 by $16.9 \%$. At 35 and $42 \mathrm{~d}$, both 
partial and total maize replacements with sorghum reduced litter moisture; the most outstanding results appeared on day 42 , reducing by $14.7 \%$ and $9.9 \%$ regarding partial and total maize replacement with sorghum, respectively. This effect may have been caused by the increased dietary potassium content, which is proportionally related to litter moisture; such effect becomes more impressive as broilers age (Ahmad et al. 2005). In this study, the higher inclusion of soybean meal in maize-based diets, compared with diets containing sorghum, was done to balance protein levels as maize has a lower level of crude protein. Soybean meal is rich in potassium (Rostagno et al. 2011); thus, it increases potassium levels in maize-based diets, impairing digesta osmolarity, and consequently, litter moisture, especially in the final period of the grower phase, as observed in broilers fed diets based on maize and soybean diets in this study.

In conclusion, sorghum can replace half of the maize in broiler diets without compromising growth performance, and on top application of an enzyme blend composed of exogenous protease, xylanase, and phytase improves performance, nitrogen retention and AMEn, regardless of the dietary cereal grain in broiler chicken from 1 to $42 \mathrm{~d}$ post hatch.

\section{Acknowledgements}

We thank Fundação de Amparo à Pesquisa do Estado de São Paulo (FAPESP) for the scholarship granted (Process 2012/18419-5).

\section{References}

Adeola, O., and Cowieson, A.J. 2011. BOARD-INVITED REVIEW: opportunities and challenges in using exogenous enzymes to improve nonruminant animal production. J. Anim. Sci. 89: 3189-3218. doi:10.2527/jas.2010-3715. PMID:21512114.

Ahmad, T., Sarwar, M., Mahr-un-Nisa, Ahsan-ul-Haq, and Zia-ulHasan. 2005. Influence of varying sources of dietary electrolytes on the performance of broilers reared in a high temperature environment. Anim. Feed Sci. Technol. 120: 277-298. doi:10.1016/j.anifeedsci.2005.02.028.

AOAC. 2000. Official methods of analysis. 17th ed. Association of Official Analytical Chemists (AOAC), Gaithersburg, MD, USA.

Brenes, A., Marquardt, R.R., Guenter, W., and Viveros, A. 2002. Effect of enzyme addition on the performance and gastrointestinal tract size of chicks fed lupin seed and their fractions. Poult. Sci. 81: 670-678. doi:10.1093/ps/81.5.670. PMID:12033417.

Brumano, G., Gomes, P.C., Albino, L.F.T., Rostagno, H.S., Generoso, R.A.R., and Schmidt, M. 2006. Chemical composition and metabolizable energy values of protein feedstuffs to broilers at different ages. Braz. J. Anim. Sci. 35: 22972302. doi:10.1590/S1516-35982006000800014.

Butler, L.G, Riedl, D.J., Lebryk, D.G., and Blytt, H.J. 1984. Interaction of proteins with sorghum tannin: mechanism, specificity and significance. J. Am. Oil Chem. Soc. 61: 916920. doi:10.1007/BF02542166.

Choct, M. 2015. Feed non-starch polysaccharides for monogastric animals: classification and function. Anim. Prod. Sci. 55: 1360-1366. doi:10.1071/AN15276.
Doherty, C., Faubion, J.M., and Rooney, L.W. 1982. Semiautomated determination of phytate in sorghum and sorghum products. Cereal Chem. 59: 373-378.

Farahat, M.H., Abdel-Razik, W.M., Hassanein, E.I., and Noll, S.L. 2013. Effect of phytase supplementation to diets varying in chloride level on performance, litter moisture, foot pad score, and gait score of growing turkeys. Poult. Sci. 92: 1837-1847. doi:10.3382/ps.2012-02869. PMID:23776272.

Hagerman, A.E., Rice, M.E., and Ritchard, N.T. 1998. Mechanisms of protein precipitation for two tannins, pentagalloyl glucose and epicatechin $16(4 \rightarrow 8)$ catechin (procyanidin). J. Agric. Food Chem. 46: 2590-2595. doi:10.1021/ jf971097k.

Huang, K.H., Kemp, C., and Fisher, C. 2011. Effects of nutrition on water intake and litter moisture on broiler chickens. Pages 26-31 in Proc. 22nd Annual Australian Poultry Science Symposium, University of Sydney, NSW, Australia, 14-16 Feb. 2011. Poultry Research Foundation, Faculty of Veterinary Science, University of Sydney, Camden, NSW, Australia.

Ikegami, S., Tsuchihashi, F., Harada, H., Tsuchihashi, N., Nishide, E., and Innami, S. 1990. Effect of viscous indigestible polysaccharides on pancreatic-biliary secretion and digestive organs in rats. J. Nutr. 120: 353-360. PMID:2158535.

Letourneau-montminy, M.P., Narcy, A., Lescoat, P., Magnin, M., Bernier, J.F., Sauvant, D., Jondreville, C., and Pomar, C. 2011. Modeling the fate of dietary phosphorus in the digestive tract of growing pigs. J. Anim. Sci. 89: 3596-3611. doi:10.2527/jas.2010-3397. PMID:21680789.

Liu, N., Ru, Y.J., Li, F.D., and Cowieson, A.J. 2008. Effect of diet containing phytate and phytase on the activity and messenger ribonucleic acid expression of carbohydrase and transporter in chickens. J. Anim. Sci. 86: 3432-3439. doi:10.2527| jas.2008-1234. PMID:18708594.

Lunedo, R., Fernandez-Alarcon, M.F., Carvalho, F.M.S., Furlan, L.R., and Macari, M. 2014. Analysis of the intestinal bacterial microbiota in maize- or sorghum-fed broiler chickens using real-time PCR. Br. Poult. Sci. 55: 795-803. doi:10.1080/ 00071668.2014.975781. PMID:25358544.

Mateos, G.G., Sell, J.L., and Eastwood, J.A. 1982. Rate of food passage (transit time) as influenced by level of supplemental fat. Poult. Sci. 61: 94-100. doi:10.3382/ps.0610094. PMID:7088787.

Matterson, L.D., Potter, L.M., Stutz, M.W., and Singsen, E.P. 1965. The metabolizable energy of feed ingredients for chickens. Research Report. Vol. 7. The University of Connecticut, Agricultural Experiment Station, Storrs, CT, USA. 11 pp.

Oria, M.P., Hamaker, B.R., Axtell, J.D., and Huang, C.P. 2000. A highly digestible sorghum mutant cultivar exhibits a unique folded structure of endosperm protein bodies. Proc. Natl. Acad. Sci. 97: 5065-5070. doi:10.1073/pnas.080076297. PMID:10792028.

Pos, J., Enting, H., and Veldman, A. 2003. Effect of phytase and dietary calcium level on litter quality and broiler performance. Pages 17-18 in Proc. 14th European Symposium on Poultry Nutrition, Lillehammer, Norway, 10-14 Aug. 2003. World's Poultry Science Association, Beekbergen, the Netherlands.

Rostagno, H.S., Albino, L.F.T., Donzele, J.L., Gomes, P.C., Oliveira, R.F., Lopes, D.C., Ferreira, A.S., Barreto, S.L.T., and Euclides, R.F. 2011. Brazilian tables for poultry and swine: feed composition and nutritional requirements. 3rd ed. Universidade Federal de Viçosa, Viçosa, MG, Brazil. 119 pp.

Sakomura, N.K., Bianchi, M.D., Pizauro, J.M., Café, M.B., and Freitas, E.R. 2004. Effect of age on enzyme activity and nutrients digestibility for broilers fed soybean meal and full fat soybean. Braz. J. Anim. Sci. 33: 924-935. doi:10.1590/ S1516-35982004000400013. 
SAS Institute, Inc. 2002. SAS user's guide: statistics. SAS for Windows. Version 9.0. SAS Institute, Inc., Cary, NC, USA.

Selle, P.H., Cadogan, D.J., Li, X., and Bryden, W.L. 2010. Implications of sorghum in broiler chicken nutrition. Anim. Feed Sci. Technol. 156: 57-74. doi:10.1016/j. anifeedsci.2010.01.004.

Spencer, C.M., Cai, Y., Martin, R., Gaffney, S.H., Goulding, P.N., Magnolato, D., Lilley, T.H., and Haslam, E. 1988. Polyphenol complexation - some thoughts and observations. Phytochemistry, 27: 2397-2409. doi:10.1016/0031-9422(88) 87004-3.

Tancharoenrat, P., Ravindran, V., and Ravindran, G. 2014. Influence of cereal type and fat source on the performance and fat utilisation of broiler starters. Anim. Prod. Sci. 55: 74-79. doi:10.1071/AN13375.

Thomas, D.V., and Ravindran, V. 2008. Effect of cereal type on the performance, gastrointestinal tract development and intestinal morphology of the newly hatched broiler chick. J. Poult. Sci. 45: 46-50. doi:10.2141/jpsa.45.46.

Wang, Z.R., Qiao, S.Y., Lu, W.Q., and Li, D.F. 2005. Effects of enzyme supplementation on performance, nutrient digestibility, gastrointestinal morphology, and volatile fatty acid profiles in the hindgut of broilers fed wheat-based diets. Poult. Sci. 84: 875-881. doi:10.1093/ps/84.6.875. PMID:15971523.
Weurding, R.E., Veldman, A., Veen, W.A., van der Aar, P.J., and Verstegen, M.W. 2001. Starch digestion rate in the small intestine of broiler chickens differs among feedstuffs. J. Nutr. 131: 2329-2335. PMID:11533275.

Wong, J.H., Marx, D.B., Wilson, J.D., Buchanan, B.B., Lemaux, P.G., and Pedersen, J.F. 2010. Principal component analysis and biochemical characterization of protein and starch reveal primary targets for improving sorghum grain. Plant Sci. 179: 598-611. doi:10.1016/j.plantsci.2010.08.020.

Woyengo, T.A., and Nyachoti, C.M. 2013. Review: antinutritional effects of phytic acid in diets for pigs and poultry - current knowledge and directions for future research. Can. J. Anim. Sci. 93: 9-21. doi:10.4141/cjas2012-017.

Wu, Y.B., Ravindran, V., Thomas, D.G., Birtles, M.J., and Hendriks, W.H. 2004. Influence of phytase and xylanase, individually or in combination, on performance, apparent metabolisable energy, digestive tract measurements and gut morphology in broilers fed wheat-based diets containing adequate level of phosphorus. Br. Poult. Sci. 45: 76-84. doi:10.1080/ 00071660410001668897. PMID:15115204.

Zhu, H.L., Hu, L.L., Hou, Y.Q., Zhang, J., and Ding, B.Y. 2014. The effects of enzyme supplementation on performance and digestive parameters of broilers fed corn-soybean diets. Poult. Sci. 93: 1704-1712. doi:10.3382/ps.2013-03626. PMID:24864292. 